\title{
THE PREVALENCE OF PASTEURELLA MULTOCIDA FROM FARM PIGS IN SERBIA
}

\author{
Oliver Radanovic, Jadranka Zutic, Dobrila Jakic-Dimic, \\ Branislav Kureljusic, Bozidar Savic

\section{Institute of Veterinary Medicine of Serbia, Vojvode Toze 14, 11000 Belgrade, Serbia}

Received 20 July 2015; Received in revised form 16 October 2015; Accepted 19 October 2015

\begin{abstract}
The investigations covered a total of 234 lungs from necropsied pigs with different pneumonic lesions, from 6 farrow-to-finish pig farms during 2013 and 2014. The samples were inoculated on selective culture media and aerobically incubated at $37^{\circ} \mathrm{C}$ and in carbon dioxide condition. The isolated bacterial colonies were further characterised morphologically and biochemically. The identification was confirmed using the BBL Crystal, E/N, G/P ID Kit (Becton Dickinson). For determination of the type of Pasteurella multocida, the PCR method was used. The findings showed that bacteria were isolated from $202(86 \%)$ out of 234 examined lung samples. The pure isolates of Pasteurella multocida were obtained from $71(35 \%)$ samples. Out of the remaining $29(14 \%)$ examined lung samples, 9, 8, 7 and 5 examined lung samples were shown as mixed cultures of Pasteurella multocida and Streptococcus spp., Arcanobacterium pyogenes, Actinobacillus pleuropneumoniae and Haemophilus parasuis, respectively. The PCR method confirmed that all 15 investigated strains of P. multocida belong to type A.
\end{abstract}

Key words: Pasteurella multocida, lung, pig

\section{INTRODUCTION}

Some of the most important problems in modern pig farming are closely related to respiratory diseases. Respiratory diseases in pigs are spread worldwide, striking substantial financial damage on livestock production systems $(1,2)$. One of the features of modern pig farming is spatial agglomeration with large numbers of individuals in limited spaces. This benefits respiratory pathogens which subsequently keep a high virulence level in vivo (3).

Among a number of factors that can cause these type of diseases, viruses and bacteria have the most important role (4). Out of many non-specific factors that can contribute to the emergence and the development of respiratory diseases, some of the most significant are overcrowded housing, bad

Corresponding author: Dr. Oliver Radanović, $\mathrm{PhD}$

E-mail address: radanovic.oliver@gmail.com

Present address: Institute of Veterinary Medicine of Serbia

Department of Microbiology, Vojvode Toze 14,

11000 Belgrade, Serbia

Phone: +381 11-285-1096

Copyright: (C) 2015 Radanovic O. This is an open-access article published under the terms of the Creative Commons Attribution License which permits unrestricted use, distribution, and reproduction in any medium, provided the original author and source are credited. Competing Interests: The authors have declared that no competing interests exist.

Available Online First: 13 November 2015

Published on: 15 March 2016

http://dx.doi.org/10.1515/macvetrev-2015-0063 hygiene, high humidity, high concentration of toxic gases, sudden temperature changes, disregarding veterinary-sanitary and biosafety measures etc.

These conditions serve in favor of persisting infectious agents in aerosol on one hand, and creating "ambient stress" on the other, which leads to immunosuppression (2). Thus, a majority of authors agree that the prevalence of respiratory diseases increases if the concentration of biological agents in their environment rises, or if the immune system in the lung tissue weakens caused by some other cause. Lung infections are usually caused by a number of factors affecting the organism at the same time, rather than individually. Most common combination of factors includes a mixed virus and bacterial infection. Pathogenic bacteria which can cause respiratory infections are Pasteurella multocida $(P$. multocida), Actinobacillus pleuropneumoniae (A. pleuropneumoniae), Bordetella bronchiseptica, Streptococcus spp. Haemophilus parasuis (H. parasuis), Actinobacillus suis (A. suis), Arcanobacterium pyogenes (A. pyogenes) and Salmonella enterica subsp. enterica serovar Choleraesuis $(4,5,6)$. Some authors agree that some of aforementioned pathogens (such as P. multocida) can be considered the primary respiratory pathogen, because of their ability to cause lesions in the lung tissue on their own (7). 
The goal of this study was to determine the incidence and identify the bacteria causing pneumonia in pigs, with an accent on the incidence of $P$. multocida.

\section{MATERIAL AND METHODS}

The pneumonic pig lungs were examined in this study. The samples originated from 6 commercial farrow-to-finish pig farms. The pigs were bred in confined production systems and the technology recommended for this type of livestock breeding
Kit (Becton Dickinson, USA). For the isolation of A. pleuropneumoniae and $H$. parasuis, additional blood agar plates with a Staphylococcus aureus streak as a source of the NAD, were incubated in jar with reduced oxygen and enhanced carbon dioxide content. Colonies suspicious to A. pleuropneumoniae and $H$. parasuis were subcultured on chocolate agar with PolyVitex (bioMerieux, France) and identified with Gram-stains, haemolysis activity on sheep blood agar, positive CAMP test, requirement NAD and urease production. For typing of P. multocida isolates, the PCR method was used according to Jaglic et al. (8).

Table 1. Incidence of certain bacteria strains isolated from 202 samples from the pig lungs

\begin{tabular}{lcc}
\hline \multicolumn{1}{c}{ Bacterial species } & No. isolates & \% isolates \\
\hline Pasteurella multocida & 71 & 35.14 \\
Haemophilus parasuis & 29 & 14.35 \\
Actinobacillus pleuropneumoniae & 25 & 12.37 \\
Streptococcus spp. & 23 & 11.38 \\
Arcanobacterium pyogenes & 15 & 7.42 \\
Mixed infection including & 29 & 14.35 \\
Pasteurella multocida & 10 & 4.95 \\
Multiple species of bacteria & 202 & 99.96 \\
\hline Total & & \\
\hline
\end{tabular}

was used. The farms where this study was conducted did not use immunization as a form of prevention against bacteria which cause pneumonia in pigs. PRRS and porcine circovirus 2 (PCV2) were both detected in those farms. The lungs sampled from the necropsied pigs were deposited in sterile PVC bags and transported to the Institute of Veterinary Medicine of Serbia for further examination.

Samples were inoculated on agar with $5 \%$ sheep blood, Columbia and MacConkey agar (HiMedia), and incubated aerobically at a temperature of $37^{\circ} \mathrm{C}$ for 24-48 h. Bacterial isolates were identified using standard bacteriological methods. The identification was confirmed using the BBL Crystal E/N, G/P, ID

\section{RESULTS}

Out of total of 234 pig lungs sampled for bacterial presence, 202 (86\%) were found positive. $P$. multocida had the highest occurrence rate found in the lung samples with $71(35 \%)$, followed by 29 samples (14\%) for $H$. parasuis, 25 samples (12\%) for A. pleuropneumoniae, 23 samples (11\%) for Streptococcus spp. and 15 samples (7\%) for A. pyogenes. From 10 (5\%) lung samples, multiple different non specific microorganisms were isolated. Results are presented in Table 1 .

Furthermore, mixed cultures of bacteria were established in 29 (14\% ) samples, where in addition

Table 2. Combination mixed culture of bacteria isolates from pig lungs

\begin{tabular}{lcc}
\hline Combination of bacterial species & No. samples & $\begin{array}{c}\text { \% of different } \\
\text { combination }\end{array}$ \\
\hline Pasteurella multocida + Streptococcus spp. & 9 & 31.03 \\
Pasteurella multocida + A. pyogenes & 8 & 27.58 \\
Pasteurella multocida + A. pleuropneumoniae & 7 & 24.13 \\
Pasteurella multocida $+\boldsymbol{H}$. parasuis & 5 & 17.24 \\
\hline Total & 29 & 99.98 \\
\hline
\end{tabular}


Prevalence of Pasteurella multocida from farm pigs

to $P$. multocida, Streptococcus spp. was isolated from 9 (31\%) samples, A. pyogenes 8 (27\%), A. pleuropneumoniae $7(24 \%)$ and $H$. parasuis 5 (17\%). Results are presented in Table 2.The PCR method confirm that all 15 investigated selected strains of $P$. multocida belong to type A.

\section{DISCUSSION}

A high percentage of $P$. multocida isolates shows that currently this microorganism is one of the most important pathogens among pneumonia causing bacteria in pigs in the farms from which the samples were collected in this study.

The importance of $P$. multocida as a main pathogen causing pneumonia in pigs was confirmed by Dutra et al. (9). Holko et al. (10) cited that $P$. multocida caused pneumonia in $44 \%$ of pigs tested. A lower percentage of $33 \%$ isolation of $P$. multocida from lung pigs was found in Serbia (11). The PCR method confirms that all 15 investigated strains of P. multocida belong to type A, which is in agreement with the reports of Stepniewska (12).

Radanovic et al. (13) found that mixed infections were determined in $6 \%$ of lung tissue samples, while other authors report an incidence of mixed bacterial infections to be $8.29 \%$ (14). It is important to note that the incidence of infections caused by mixed bacteria cultures increased on $14 \%$ in the pig farms in Serbia.

Mixed infections of lung tissue are also reported by researchers, who, among other bacterial causative agents, also report a prevalence of viruses which cause pneumonia in pigs, especially a coinfection with the PRRS virus. Choi et al. (15) report a prevalence of coinfection with PRRS and $P$. multocida to be $10.4 \%$, PRRS and M. hyopneumoniae of $7 \%$ and PRRS and A. pneumoniae to be $6.2 \%$. Also, the mixed infections have been described in several studies $(16,17,18,19)$. In these studie,s the more common mixed infections were $P$. multocida with viruses or bacterial agents.

All of the farms from which the samples were collected reported the presence of either PRRS or PCV2, or both viruses. In previous research in Serbia, the positive samples of PRRSV were found in all examined regions, in 14 of $20(70 \%)$ examined farms (20). Also, PCV2 is a ubiquitous virus of pigs, and all of 12 examined farms have experienced PMWS over the time. One or both viruses tend to produce both local (lung tissue) or systemic immunosuppression, which is believed to help develop lethal bacterial pneumonia (21). The result of immunosuppression is lower defensive activity towards different microbial agents, especially to bacterial antigens, which leads to the conclusion that the control of these viral infections is of great importance concerning the respiratory disease control.

These results and other similar findings, must be well explained regarding the global trend in the recent years. It has been determined that, after the infection with PRRS and PCV2, bacterial isolates often differ both between the animals in the same group, and between different production groups in the same farm. The explanation for this occurrence can be found in the individual differences between animals, their different ability to react to antigens and the diverse immune status of rears as the result of the immunosuppressive activity of the aforementioned viruses.

\section{CONCLUSION}

Bacteriological examination of pig lungs with pneumonic lesions showed the presence of bacterial pathogens in $86 \%$, which points to the significance of bacterial causative agents in the ethiopathogenesis of pig pneumonia in this studied farms.

The high prevalence of $P$. multocida $(35 \%)$ and the prevalence of $P$. multocida in mixed infections (14\%) was also found. Such a high percentage of the isolation of $P$. multocida indicated its important role in the occurrence of respiratory infections of swine on our farms with intensive production systems. Compared to the previous period, the incidence of mixed bacterial infections was higher.

\section{REFERENCES}

1. Bochev, I. (2007). Porcine respiratory disease complex (PRDC): A review. I. Etiology, epidemiology, clinical forms and pathoanatomical features. Bulg. J. Vet. Med. 10, 131-146.

2. Savić, B., Radanović, O., Žutić, M., Pavlović, I., Jakić-Dimić, D. (2011). Prevalenca bakterijskih uzročnika pneumonija svinja. IX Simpozijum Veterinara "Zdravstvena zaštita, selekcija i reprodukcija svinja”. Zbornik radova. 77-82. Srebreno Jezero.

3. Woeste, K. Grosse, E. (2007). Transmission of agents of the porcine respiratory disease complex (PRDC) between swine herds; a review. Part 2-Pathogen transmission via semen air and living/nonliving vectors. Deutsche. Tierarzt. Wochenschrift. 114, 364-373.

PMid:17970334 
4. Baker, R.B. (2005). Diseases of the respiratory system. Proceedings of the North Carolina healthy hogs seminar. Clinton. 1-19. PMCid:PMC4147871

5. Halbur, P.G. (1997). Porcine respiratory disease complex, Proceedings of the North Carolina healthy hogs seminar. 1-15.

6. Lee, A. (2013). Mycoplasmal pneumonia in pigs, 1-3. http://www.dpi.nsw.gov.au

7. Tigga, M., Ghosh, R.C., Malik, P., Choudhary, B.K., Tigga, P., Nagar, D.K. (2014). Isolation, characterization, antibiogram and pathology of Pasteurella multocida isolated from pigs, Vet. World 7, 363-368.

http://dx.doi.org/10.14202/vetworld.2014.363-368

8. Jaglic, Z., Kucerova, Z., Nedbalcova, K., Pavlik, I., Alexa, P., Bartos, M. (2005). Characterisation and comparison of Pasteurella multocida isolated from different species in the Czech Republic: capsular PCR typing, ribotyping and dermonecrotoxin production. Vet. Med. - Czech. 50 (8): 345-354

9. Dutra, V., Chitarra, C., Paula, D.A. (2013). Detection of Pasteurella multocida by qPCR Associated with Ppneumonic lung in pigs slaughtered in M Grosso Brazil. Int. J. Sc. 2,25-31.

10. Holko, I., Urbanova, J., Holkova, T., Kmet, V. (2004). Diagnostics of main bacterial agents of porcine respiratory diseases complex (PRDC) using PCR detection of Mycoplasma hyopneumoniae. Vet. Med. - Czech. 49, 35-41.

11. Radanović, O., Savić, B., Kureljušić, B., Ivetić, V., Žutić, M. (2010). Učestalost izolacije Pasteurella multocida iz pluća prasadi iz kategorije odgoja.Proceedings of the XII Symposium of Epidemiological days with international participation. Oplenac-Topola. 99-102.

12. Stepniewska, K., Markowska-Daniel, I. (2013). Phenotypic and genotypic characterization of Pasteurella multocida strains isolated from pigs in Poland. Bull Vet Inst Pulawy 57, 29-34.

13. Radanović, O., Žutić, M., Ivetić, V., Savić, B., Stanojević, S. (2008). Significance of Pasteurella multocida in respiratory disease complex of swine. Proceedings of the X Symposium of Epidemiological days with international participation. Tara. 253-255.
14. Žutić, M., Ivetić, V., Radanović, O., Žutić, J., Jakić-Dimić, D., Savić, B., Pavlović, I., Stanojević, S. (2009). Investigations of representation of certain bacteria strains in lungs of pigs with pneumonia. Vet. Glasnik 63, 3-15.

http://dx.doi.org/10.2298/VETGL0902003Z

15. Choi, Y.K., Goya, S.M., Joo, H.S. (2003). Retrospective analysis of etiological agents associated with respiratory diseases in pigs. Can. Vet. J. 44, 735-737. PMid:14524628 PMCid:PMC340270

16. Hansen, M.S., Pors, S.E., Jensen, H.E., Bille-Hansen V., Bisgard, M., Flachs, E.M., Nielsen O.L. (2010). An investigation of the pathology and pathogens associated with porcine respiratory disease complex. in Denmark. J. Comp. in Denmark. J. Comp. Pathology. 143,120-131. http://dx.doi.org/10.1016/j.jcpa.2010.01.012 PMid:20181357

17. Opriessnig, T., Gimenez-Lirola, L.G., Halbur, P.G. (2011). Polymicrobial respiratory disease in pigs. Anim. Health. Res. Rev. 12,133-48. http://dx.doi.org/10.1017/S1466252311000120 PMid:22152290

18. Weissenbacher-Lang, C., Kureljušić, B., Nedorost, N., Stixenberger, D., Binanti, D., Viehmann, M., Weissenböck, H. (2014). Association between Pneumocystis carinii and bacterial lung pathogens in pigs with pneumonia. Proc. 23rd IPVS Congress,Cancún, Mexico, 08.06.-11.06.2014. p. 53.

19. Pors, S.E., Hensen, M.S., Christensen, H., Jensen, H.E., Petersen, A., Bisgard, M. (2011). Genetic diversity and associated pathology of Pasteurella multocida isolated from porcine pneumonia. Vet. Microbiol. 150, 354-361 http://dx.doi.org/10.1016/j.vetmic.2011.02.050

20. Petrović, T., Miličević, V., Radulović-Prodanov, J., Maksimović-Zorić, J., Lupulović, D., Došen, R., Lazić, S. (2011). Molecular detection and genetic analysis of Serbian PRRSV isolates. Euro PRRS Symposium. Proceedings pp. 50-56. 12-14 October Novi Sad.

21. Truszczyński, M., Pejsak, Z. (2010). Immunosuppression as the cause of swine diseases of multifactorial etiology. Meycyna Wet. 66, 370-373. 